\title{
Doctors into Agents: The Technologies of Medical Knowledge and Social Control in State Socialist Hungary*
}

\author{
Viola Lászlófi \\ Eötvös Loránd University / École des Hautes Études en Sciences Sociales \\ viola.laszlofi@ehess.fr
}

In this paper, I analyze different situations in which the doctor-patient relationship, the knowledge/information produced within this framework, and the practices of medical questioning came to the fore in the work of the state security services, one of the typical institutions of social observation and surveillance of the Hungarian socialist state. I examine work and recruitment dossiers opened from 1956 to the 1980s which document either physicians' uses in state security observation of information which they gained about their patients during their professional (medical) activities in or in which the physician-patient relationship appears as a context of the physician's recruitment. I discuss how physicians constructed the patient when the gaze of the state security forces was also arguably part of their medical gaze. I contend that medical knowledge and, more generally, information revealed in the professional (medical) context and used in the framework of network surveillance, taken out of their strict medical context, constituted a gray zone of power. On the one hand, this information was a useful tool with which the regime could exert some measure of effective social and political control beyond the borders of healthcare, while on the other hand, it could help physicians develop a certain degree of social resistance.

Keywords: state socialism, history of medicine, state security, doctor-patient relationship, gray zone of power

From end of the 1940 s, the developing state socialist system aimed to modernize several facets of social and political life in Hungary. Building on the social and ideological objectives of the new system and conforming to international tendencies, the state engaged in a comprehensive pursuit of modernization which encompassed the provision of welfare benefits, such as universal healthcare, the development, extension and structural reorganization of which began in the early years of the state socialist regime. ${ }^{1}$ As early as the 1940 s, the directive of providing more citizens with health insurance and creating a state-funded

\footnotetext{
* My research enjoyed the support of the ÚNKP-20-3 New National Excellence Program of the Ministry of Innovation and Technology from the Source of National Research, Development and Innovation Fund. 1 On the history of the Hungarian state socialist regime's political and social changes, see Borhi, Hungary in the Cold War, Gyarmati and Valuch, Hungary under Soviet Domination.
} 
universal basic healthcare system yielded the restructuring of healthcare in many countries. This process intensified significantly after World War II. ${ }^{2}$ By 1961, with the extension of universal health insurance, almost all citizens were eligible for healthcare in Hungary, and after 1975, it became accessible essentially for free to the whole population. ${ }^{3}$

The de-privatization of the existing healthcare institutions and the establishment of new hospitals, the extension of the network of general practitioners, and the development of outpatient care enabled access to healthcare for both urban and rural populations. Healthcare providers, who previously operated private medical practices, were now employed by the state. ${ }^{4}$ By introducing these measures, the reigning party's aims were to advance the medicalization of society and to create an institutional framework which would symbolize the provision of a high level of public care for the workers, the group favored by the state socialist system but marginalized by previous regimes. ${ }^{5}$ Consequently, medical knowledge and the doctor-patient relationship as a form of social interaction came to play a decisive role in molding socialist welfare. This

2 In England, following the National Service Act in 1946, most healthcare institutions were de-privatized, providing health insurance for 96 percent of the population, whereas in Sweden, the whole population was allowed access to insurance and universal healthcare from 1955. For more on this see Fülöp, Nébány tókés ország, 3-43; Light, "Universal Health Care."

3 In Hungary, before the end of 1950s, a significant number of peasants kept their land ownership and thus remained independent farmers without insurance. It was only the third attempt of agricultural collectivization from 1958 to 1961 which was successful; thus, the majority of agricultural workers were insured only from the 1960s.

4 On these changes see Szalai, Az egésæségingy betegségei, 53-75; Hahn, A magyar egészségügy története, 144-87.

5 The concept of medicalization has several definitions in the social sciences (see van Dijk et al. "Medicalization Defined in Empirical Context.") In this study, this term refers to the processes by which the human body and behavior as well as different activities and characteristics became the subject of medical activity and discourse in modern societies. Aside from accepting the fact that the more extensive use of medical knowledge serves the wellbeing of individuals, the concept of medicalization provides an opportunity to analyze these changes as the manifestations of growing social control. However, if we consider the Hungarian case, even though the social history of state socialist healthcare has hardly been studied and it is thus hard to tell how political intentions were realized on a micro-level, the problems emphasized by the different state regulations and the extension of medical care to prioritized groups provide some insight into how the party state might have imagined the project of medicalization. Which social groups were to be medialized, and how? According to the ideological, social, and economic goals of the state, the development of hospitals and outpatient care and the organization of a system of GPs and factory doctors (both in the cities and the countryside) shed light on and helped provide a solution mainly to the physical problems of industrial and agricultural workers. In addition, the emphasis on well-organized health education programs and prophylaxis suggests that ideal individuals in a state socialist society were not just able to think about their existing problems in a medical framework but were also aware of different ways of maintaining their health and preventing illnesses. 
process and its implications have been addressed in sociological inquiries, but historians have not yet given them adequate study or interpretation. ${ }^{6}$ However, the cases have not been examined in which doctors, who by then had come to fulfil a fundamental role in welfare provision and thus had a higher number of social contacts than they earlier had had, became the agents of state power not only on account of their medical knowledge but also as the employees of the state security forces, which was one of the key institutions of political repression, responsible for monitoring and controlling individuals in society. In this study, I focus on these rare but all the more significant instances when the state security's gaze exerted an influence on (and arguably was part of) the medical gaze. The cases under study constitute only a small proportion of the state security files reflecting on the performance of physicians, which means that the position physicians enjoyed in society (as figures in whom trust and confidence was placed), which was clearly considered beneficial for the intelligence network, was little exploited.

As a well-definable group of people possessing specialized knowledge and the related power, physicians have already been discussed in Michel Foucault's works. Foucault perceived power as a set of techniques, maneuvers, and functions which are distributed based on the strategical positions occupied by individuals or groups within a society. Power, furthermore, is operational, and it thus applies in social contexts and systems of relations in which both bottom-up and top-down processes are observable, and both the dominant and the dominated groups participate in developing power relationships. ${ }^{7}$ In a medical context, this power could find expression in various phenomena, from medical consultation to health education, and due to the constant presence and operation of power, individuals learn and practice required behaviors, and these processes and rituals of adaptation play a fundamental role in maintaining social

6 The research of Ágnes Losonczi and Júlia Szalai merits particular mention. The studies published in the 1970s and 1980s discuss the anomalies of healthcare, such as the vulnerability of both patients and physicians within the system or the difficulties of accessing quality care. Losonczi and Szalai identify the peculiarities of the development of socialist healthcare as an underlying reason to these tensions. In their works, the history of the transformation of healthcare is examined from the point of view of structural errors. See for example: Losonczi, A kiszolgáltatottság anatómiája; Szalai, Az egészségügy betegségei.

7 Foucault's views on power were summarized more or less coherently in Discipline and Punish, later elaborated on in lectures and interviews: Foucault, Discipline and Punish, 135-309; Foucault, "The Eye of Power." On the aspects discussed in this article see Deleuze, Foucault, 34-38. 
order. In short, people become medicalized. ${ }^{8}$ There are, however, two aspects which weaken the force of this argument in the context of socialist Hungary. Foucault's observations apply primarily to a capitalist context. Furthermore, he presumes that, although medical and state power are closely related, they cannot be reduced each to each other. The relationship between them should be the subject of further analyses in different social and political contexts.

Taking these arguments as my point of departure, in this study I seek to outline the different aspects and functions of medical activity (institutional, social, responsibility for the production of knowledge) which made doctors and their knowledge of interest outside of healthcare contexts or, the other way round, which impeded the use of this knowledge in new contexts. I also seek to address how the methods used primarily in medical contexts by healthcare experts were used and interpreted during their work within the network of the state security forces. Based on the available evidence, I argue that the methods and practices of the production of knowledge used during medical fieldwork within an institutional context (the development of trust in the doctor-patient relationship, the making of diagnoses) and the social control obtained through such practices produced a certain gray zone of power $^{9}$ when they were adopted in the framework of state security observation. On the one hand, doctors, due to their social-institutional power, could exert significant social control, but on the other hand, this very power could enable them to put up a certain amount of resistance.

In examining this phenomenon, I explore recruitment and work dossiers, altogether 10 , which center on information obtained in a medical context by doctors who had already worked as agents or who were only being pursued

8 On the application of Foucault's perception of power to specifically medical contexts see Hancock, "Michel Foucault and the Problematics of Power"; Peerson, "Foucault and the Modern Medicine."

9 This expression was first used in a historical context by Primo Levi. This research, however, benefits more from two different takes on the concept. The sociologist Alan Blum, devoting particular attention to the contexts of healthcare and the approaches to health and sickness, explained "gray area" as the unsaid ambiguities that yield decisions from a certain individual and that are influenced by unsaid presumptions and interpretive processes. Sándor Horváth, working in different a field, but within the context of state socialism, described the type of historical knowledge production as a "gray zone" which occurs "in the shadow of the official propaganda" and is thus either weakly related or unrelated to it (Blum, The Grey Zone of Health and Illness, 1-17; Horváth, "A helytörténetírás mint szürkezóna," 89). In creating my concept, I build on Blum's approach by considering the professional and social autonomy of physicians in decisionmaking. As for Horváth's understanding of the concept, I find the examination of relations between "official" and "non-official" knowledge in a certain area especially useful. 
by state security. ${ }^{10}$ All of them were written after the 1956 Revolution in the Kádár era, but their distribution within this period varies between diverse dates. The exact dates are always indicated in the footnotes. As for the content of the dossiers, however, there are no significant differences. Through the lens of the dossiers, we catch a glimpse into a rather heterogenous medical practice, as the doctors in question had a diverse array of expertise (psychiatry, neurology, family medicine, inner medicine), came from a geographically heterogeneous background, and worked in different institutional settings (hospital, local practice, psychiatric institution). Due to the lack of documentation, in several cases it is not known why or how they were recruited by the secret police. The recruited physicians were classified into several categories, such as agents, informants, and secret emissaries. ${ }^{11}$ As these nuances of classification are unimportant in interpreting the information the doctors obtained and thus in answering my research questions, for the sake of simplicity, I refer to them as informants and/ or agents. Their exact functions are summarized in Table 1 (see below).

\section{Social Control and the Production of Knowledge}

To be able to grasp how the doctors' opportunities to become useful informants, their work for the secret police, and the usefulness of their reports were evaluated and how this related to the distinguishing characteristics of their profession, in short, whether a gray zone was indeed supervened, first, it is worth giving a brief summary of earlier research on the "success" of state security observation and the agents whose role was indispensable to this success.

As has been pointed out by a number of studies focusing on the practices of the production and interpretation of state security reports, which are fundamental to any understanding of how the system itself worked, an analysis or discussion of the observational techniques used by the secret police forces, such as the Romanian Securitate, the East German Stasi, or the Hungarian

10 In addition to the instances examined in this study, doctors helped the work of the secret police on numerous occasions. A typical case was participation in research trips, in, for example, factories or conferences, which often benefitted the development of scientific relations and at the same time offered an opportunity to write lengthy reports on individuals.

11 Classification depended on the role the recruited individual held within state security forces. While the agents' task encompassed both the acquisition of information and the prevention of seditious activities against the state, the latter was not expected of informants. The function of "secret emissary" was created during the restructuring of state security in 1972-1973, and their role was similar to the roles of the informants. See Rainer, Jelentések, bálójában, 70-75. 
State Protection Authority, may do little to further our knowledge of the actual social realities of the time. ${ }^{12}$ Secret polices forces were created to strengthen socialist systems and to prevent disruption within society. Thus, one of the tasks entrusted to these police forces was the creation in their reports of a discourse which buttressed both the terminology and the reasoning of the state ideology. The creation of this discourse allowed the regimes to label allegedly disruptive events using terms that reinforced the state narrative (for instance, espionage or sabotage) and to identify perpetrators as culprits from this narrative (for instance, the saboteur, the bourgeois, and the kulak). In course of time, the state security forces were given new missions, and their protective functions, which purportedly were intended to advance the building of socialism through the pursuit of complete control over society and the protection of the social order, were replaced with an all-encompassing ubiquity and the wish to know and monitor every minor secret of each and every citizen. ${ }^{13}$ According to János Rainer M., in the Hungarian case, this change had been implemented by the 1960s. ${ }^{14}$ This alteration of functions, however, left the linguistic construction of reports untouched: reports still had to be written in a language interpretable (and acceptable) to both the state security force and the party.

The informants' ability to fulfil their mission (to observe and to meet the expectations placed on them with regards to their reports) was strongly influenced by their relationships with case officers. Katherine Verdery drew on the analogies between the system of state security and educational institutions, and Sándor Horváth has compared the connection between informants and their case officers to the teacher-pupil relationship. ${ }^{15}$ Horváth argues that the individuals' first reports within the state security system and the case officers' criticism of their form and content could be perceived as part of a process of socialization and learning during which the informants appropriated the

12 See for example Verdery, Secrets and Truth; Vatulescu, Police Aesthetics; Bolgár, "A hatalom mindennapjai."

13 The transformation of the state security force's function was related to the consolidation of the Kádár regime. Since the 1960s, the legitimacy of Hungarian state socialism was based on the acceptance of the state party's will in economic and social questions and on the success of welfare reforms (for example, rising living standards and the relative freedom of individuals as compared to the Stalinist era), rather than on the different forms of terror and fear. Mary Fulbrook described a very similar process in the case of the GDR in the 1960s and 1970s, to which she refers as the period of "returning to normal." (Fulbrook, "The Concept of 'Normalization'.')

14 Rainer M., Jelentések hálójában, 262. According to Verdery, a similar change took place in Romania in the 1970s. Verdery, Secrets and Truth, 17.

15 Verdery, Secrets and Truth, 170-73; Horváth, "Life of an Agent." 
fundamental methods of their new "work," such as the logic and formal requirements of report writing, as well as the perception of their own social environment based on either opposition to or conformity with the system. ${ }^{16}$ This knowledge, at the same time, could prove flexible, and it could be used by the informants to pursue their own personal goals through the secret police. Moreover, the teacher-pupil concept reflects the (limited) flexibility of this relationship. The success of gathering information and the efficiency of the relationship were determined not only by the officer's intentions to educate and socialize the informant/pupil, but also by how successfully the two actors asserted their own will in their collaboration.

The teacher-pupil relationship as a metaphor, however, is not only relevant from the perspective of learning and socialization. It is also a great signifier of another, psychologically more sensitive interpretive process, a core element of the paternalistic, almost controlling relationship between informants and their case officers. The primary focus of this is not the report written by the informant, but his behavior, personal dilemmas, and social status. As the textbooks on operative psychology (written particularly for case officers) reveal, ${ }^{17}$ the individual's personality and his eligibility to work within the network of state security were considered as early as recruitment plans were written, and recruits were continuously assessed from the perspective of their psychology during their operation within the network, for example, in instances when the sincerity of their reports was evaluated. ${ }^{18}$ Qualities such as intelligence, good memory, learning ability, politeness, and attentiveness were highly desired, but it was also considered valuable if the individual was ideologically trustworthy and had a wide social network on which he could rely during his work within

16 Horváth, "Life of an Agent." The "gaze of the state security" is explored by Éva Argejó through textbooks and educational films made specifically for case officers. Her article depicts how this gaze is created through the visual perception and interpretation of the people observed and their surroundings. Argejó, "Az állambiztonsági tekintet."

17 Operative psychology served the purposes of securing cohesion within the network of state security, obfuscating, disorganizing groups built on solidarity, and confusing individuals in order to undermine social confidence. Betts, Within Walls, 41.

18 These textbooks were used in the training of case officers, and they were secret or top secret and intended for internal use only. A strong psychological aspect was included after 1972, following an order from the Ministry of Interior. The subsequent issues followed the current psychological trends of the second half of the twentieth centuries, incorporating both the basics of physiology and the theories of Edward Lee Thorndike, Erich Fromm, and Albert Bandura. 
the network. ${ }^{19}$ Though timidity or nervousness, which were seen as weaknesses since they might lead to the unmasking of secret activities, were not considered so dire as to disqualify a potential recruit, case officers were trained thoroughly to be able to motivate their informants (who had different personal values and came from diverse social backgrounds) to work efficiently. Since the informants had no insights into the operation and aims of the state security forces beyond the immediate world of their specific tasks, the case officers, taking on the role of "psychologists" and "sociologists," had to use different tactics to secure the success of the operation. They were responsible for noticing and addressing the mental problems that could arise from stressful situations, and they had to have an extensive knowledge of the informant's social network and its usability. This knowledge was essential if the case officers were going to give their informants.

\section{Doctor-Patient Relationship as the Situation of Observation}

The value of informants in the eyes of the state security forces thus depended not only on the content and form of their reports, but also on their psychological characteristics and social embeddedness as the preconditions of a systematic acquisition of information. Following this line of thought, first I examine the aspects of medical practice that made doctors desirable as informants in the eyes of the state security forces.

The case of "Tarköi" sheds light on why and how medical activity could be either the reason, the aim, or the circumstance of recruitment. In October 1957, when the 32-year-old "Tarköi" was approached by the agents of the secret police, he was working as a general practitioner in Miskolc, though he had originally been trained as surgeon. ${ }^{21} \mathrm{He}$ was recruited because of his participation as a physician in the 1956 Revolution: he organized first aid stations in the "counterrevolutionary centers" of Miskolc. ${ }^{22}$ It was not uncommon for agents of

19 ÁBTL 4.1A-3120. Ivan in, Az operativ pszichológia nébány kérdése, 49-85; ÁBTL 4.1. A-31.21. Láng, Operativ pszichológia III. 11-24; ÁBTL 4.1. A-4510; Horváth, A pszichológia és szociálpszichológia felhasználása.

20 For the sake of anonymity, in the case of officers and informants, their code names are used and in the case of patients their initials are used.

21 The dossiers do not reflect on the reasons behind this change of medical specialties.

22 ÁBTL 3.1. B-92993 “Tarkői”, 5-10. It was very common, especially in the early years of Kádár era, for individuals to be blackmailed by the state security forces to join the network because of their (real or supposed) participation in the 1956 Revolution or their other politically intolerable activities. In the context of the GDR, Francesca Weil's research has shown that for doctors who provided information for the Stasi, in addition to fostering their institution and their own personal interests and fear, blackmailing those 
the state security forces to approach someone because of his or her participation in the events of the revolution. In many cases, a person who had participated in the revolution would be under pressure to cooperate with the authorities simply out of fear of the potential consequences of refusal were he or she to refuse. The state security forces, furthermore, were also motivated to approach such individuals in the hopes of uncovering other "counterrevolutionaries." The case of "Tarkôi," however, is different. The professional and political norms in this case are in stark opposition: as far as the medical explanation goes, as "Tarköi" had taken the Hippocratic Oath, he was ethically obliged to provide each sick or injured person proper medical care during the revolution. ${ }^{23}$ Thus, he was only fulfilling his professional duty. In the eyes of the state security forces, however, his medical-professional activity was understood as advancing the success of the "counterrevolution."

The first encounter between the case officer and "Tarkôi" occurred in a medical context, when the officer visited him as a patient suffering from a contagious disease. The goal of his visit was to get to know the doctor and to assess his eligibility. The case officer's two-page report portrays a professionally competent physician with a wide social network, or in other words, a suitable candidate for the role of informant. As the officer reports, "Tarköi" "received him with great politeness," examined him thoroughly, wrote a prescription, and engaged in pleasant conversation about the local problems of healthcare and his own life and past. The "well-trained" doctor "had a good memory and good conversational skills." He was not "verbose, but rather direct and friendly." 24 "Tarkôi”" was thus the ideal type of a socialist physician, and he met all the

who had previously attempted to leave the country provided an important means of recruitment. (Weil, Zielgruppe Ärateschaft, 281-91.) As far as I know, a comprehensive study has not been done concerning the different reasons for recruitment in the Hungarian context. Thus, the proportion of cases in which blackmail was used is unknown. However, in the late 1950s, the indication of the "social category" of the recruited individual was one of the most important detail in the register file. According to these categories, one could have been a kulak, a member of the former ruling classes, a member of former fascist and bourgeois organizations, a counterrevolutionary, a Zionist, or a rightwing smallholder. (See Takács, "Az ügynökhálózat társadalomtörténeti kutatása," 118-19.) Using this part of the documents, it was easy to determine whether an individual was a friend or foe of socialism. This information could also be used to recruit individuals.

23 Since the Hippocratic Oath encompassed the obligations of doctors to their patients, in, for example, the Soviet Union, certain elements of the original version were eliminated that did not conform to the official ideology, among them the requirement of medical privacy. Bernstein, "Behind the Closed Doors," $106-7$.

24 ÁBTL 3.1. B-92993 “Tarkői”, 19-20. 
requirements that a medical professional had to meet to serve both individual patients and society properly. In the medicalization of society, the individual doctor-patient relationships were given great significance, and one of the most important components of these relationships was personal sympathy. ${ }^{25}$ Furthermore, as pinpointed by studies in the period, this confidential relationship had a substantial impact on the recovery of patients, so "Tarköi's" behavior would have been a perfect foundation for an ideal doctor-patient relationship if he was visited by a real patient. ${ }^{26}$

This confidential conversation on "Tarkői's" professional qualities also offered a good opportunity to evaluate his potential as a good informant: his caring and attentive nature and his proneness to "flattery" made him a trustworthy and ideal candidate in the eyes of agents of the secret police. ${ }^{27}$ Furthermore, "Tarkői's" future case officer got a clearer idea of his social network. He concluded that "['Tarkői'] knows people from different [social] backgrounds well. Some of his patients have functions either in the party or the state bureaucracy." Though the officer wished to point out "Tarkői's" wide clientage and the value of his work for the community, the underlying logic shows the categorization of individuals according to their relationships with the state socialist system. This prefigures the potential aspects of observation. ${ }^{28}$ Consequently, the case officer's report shows "Tarkői” as an ideal candidate due to his wide social network and trustworthy nature. His professional qualities could also easily be translated into the new context.

Confidence in the case of an ophthalmologist from Kalocsa in Southern Hungary, who worked under the code name "Siva," and his case officer was built on an appealing doctor-patient relationship and an underlying existential vulnerability. "Siva" started working for the network in 1953, and by 1962, when his assignment was changed, he was already an experienced informant. From 1962 onwards, he was ordered to observe and report on the activities of W., one of his close acquaintances, who also happened to be his patient. The dossier

25 Farádi, "Dialektikus materializmus a gyakorlati," 819-20.

26 Balint, "The Doctor, his Patient and the Illness." The relationship between practitioner and his patient, especially the confidential communication required in this context and its therapeutical benefits, were fundamental principles of the humanistic medical movements of the second half of the twentieth century. See for example Bates, "Yesterday's Doctors."

27 ÁBTL 3.1.1. B-92993 “Tarkői”, 20.

28 The monitoring of party members, the elite group of state socialism, was not among the tasks of the state security forces. These individuals were held to account, rather, in the context of party disciplinary procedures. See Koltai, Akik a "Párt" ellen vétkętrek, 83-115. 
reveals that W. turned to "Siva" for advice on numerous occasions and even recounted some aspects of his clerical activity that could have been seen by the authorities as seditious. ${ }^{29}$ This confidentiality in itself could have been exploited by the secret police, but the doctor-patient relationship, which was formed after they had already grown close owing to their common interest in music, added another layer to it. This new aspect made their relationship, which had been casual, in certain respects hierarchical and formal. ${ }^{30}$ The case officer, realizing this change in power relations, decided that from then on, observation should occur in a new, medical context: "The pretext of the invitation should be a follow-up examination after a previous illness. [...] As his doctor, he should reassure him [W.] about his condition. He should point out that with occasional check-ups, he would recover completely. He should offer his services, help, and complete confidentiality. Thereafter, he could get to the point [investigating potential seditious activities]." 31 Regular meetings necessitated by the condition of W.-[meetings] that allegedly served [W.'s] interests — secured the opportunity for further inquiries and for maintaining a confidential relationship. W. was thus observed in a delicate situation, in which the patient is both vulnerable and is expected to confide in his caretaker. ${ }^{32}$ Though vulnerability is not mentioned explicitly in the above passage, by instructing the informant to calm the patient, the case officer implicitly suggests that he expects the patient to be anxious in a situation in which the doctor's diagnosis clearly would have consequences for his perception of his physical and mental wellbeing, short-term and long-term. And even though questioning about potential seditious activities followed the physical examination, the situation itself and the conscious reflection on the potential feelings it could induce all suggest that the doctor-patient relationship was viewed as more valuable from the point of view of observation than other,

29 ÁBTL 3.1.2. M-18864/1 "Siva." Assignment plan, Cegléd, January 2, 1962. 84.

30 There were voices on both sides of the Iron Curtain speaking out against the hierarchical nature of the doctor-patient relationship, however. In a reconsidered framework, as propagated, for example, by Michael Balint, patients could play an active role in their recovery. In the state socialist context, conforming to the ideological expectations, this could mean an equal relationship between two workers. In the Hungarian case, this initiative was unsuccessful, and the hierarchical doctor-patient relationship remained dominant. Losonczi, A kiszolgáltatottság anatómiája, 15-22.

31 ÁBTL 3.1.2. M-18864/1. "Siva." Assignment plan, January 2, 1962. Cegléd, 1962, 84-85.

32 Losonczi, A kiszolgáltatottság anatómiája, 9-15. A similar case to "Siva’s," founded on the patient's vulnerability, is found in the dossier of the agent who worked under the code name "Orvos." He was also ordered to summon his patient for a visit and to inquire about potential seditious activities. As the two situations show striking similarities, I will not analyze this case in more detail here. ÁBTL 3.1.2. M-17764/1. “Orvos," 340-41. Report, Budapest, January 12, 1961. 
even closer relationships (close acquaintance, friendship), as it was founded on (physical) vulnerability.

"Siva's" case officer considered the doctor-patient relationship useful because of its official, hierarchical nature and its confidentiality, which made it a rich source of information. The information obtained concerning the patients' activities and social relations during examination and treatment, however, did not necessarily have to be used by the agents of the secret police: the protection of privacy and the prohibition of the use of information outside of the administrative context of healthcare were regulated, and under state socialism, all patients had the right to medical privacy. ${ }^{33}$ This regulation, which simultaneously served the doctors' professional autonomy and the protection of patients, even if the extent of medical privacy was not generally agreed upon, encompassed all information (regardless of its nature) that came to light in medical contexts. ${ }^{34}$ Divergence from the principle of medical privacy because of loyalty to the system or fear of the state security forces will be discussed later. The question of whether the case officers reflected on the norm of medical privacy and its impact on the work of the secret police should be addressed here.

This phenomenon is discussed only once, in the case of a doctor who used the code name "Szentedrei," though whatever qualms he may have had about protecting patient privacy, they do not seem to have hindered his activities as an agent. "Szentendrei" was a psychiatrist, and at the time in question, he worked as a primary physician at the Institute for Work Therapy in Pomáz. He had a rather wide social network. One of his close acquaintances was a man named György Krassó, ${ }^{35}$ who was a significant member of the opposition in the Kádár era. At

33 1959, Decree No. 8. Medical Regulation. 10.5; 11/1972. (30. VI.), Regulation of medical workers issued by the Ministry of Health. \. 22. The introduction of medical privacy was far from self-evident in the Eastern Bloc. In the Soviet Union, a doctor's obligation to keep delicate information private was not regulated legally and was not discussed in professional circles. Furthermore, the passage referring to medical privacy was eliminated from the original text of the Hippocratic Oath (Bernstein, "Behind the Closed Doors").

34 In state socialist countries, even in the authoritarian and repressive context of the political-social system, there remained circles of trust that did not allow individuals to atomize completely. On this, see for example Hosking, "Trust and Distrust," 17-25; Betts, Within Walls. There were several factors, however, that could affect this confidentiality within the doctor-patient relationship (for example, society's attitudes towards alternative medicine were replaced entirely by Western medicine in the period or the attitudes towards doctors seen as "bureaucrats"). This will be discussed in my $\mathrm{PhD}$ dissertation in more detail.

35 György Krassó (1932-1991) participated in the events of 1956 and was later sentenced to 10 years in prison. He left prison in 1963 after János Kádár issued a general amnesty. In the 1970s, he became an active member of the opposition, and in 1982 he established the Magyar Október [Hungarian October] press, which published several samizdats. He was under constant surveillance and was arrested several times. 
Krassó's request and with the case officer's approval, "Szentendrei" examined Krassó's French female friend. The woman "subjected herself to an almost oneand-a-half-hour medical examination," the results of which were to be delivered to the French woman's Hungarian friend, but "keeping medical privacy in mind." ${ }^{36}$ In this case, medical privacy not only did not hinder the work of the secret police, but appears to have confirmed "Szentendrei's" trustworthiness. "Szentendrei's" willingness to ignore the patient's right to privacy casts light on his work not only as a doctor, but also as an agent. He shared information with the state security forces that he did not necessarily share with someone who was close to the patient (Krassó).

In conclusion, medical activity and the doctors' position within this context were associated in the eyes of the secret police's agents with both social confidence and reliability, as well as exploitable vulnerability. Moreover, physicians, who conformed to the norms of modern medical practice had character traits that were perceived as desirable in their new "work environment" within the network of state security.

\section{The Perception of Medical Knowledge within the Network}

Medical diagnosis, social prognosis

So far, we have seen that doctors were considered ideal informants, but we have not touched on how the actual methods they used to diagnose and cure their patients were understood in this new context. How did the medical gaze construct its patient when the state security's gaze was absorbed into it? ${ }^{37}$

An agent who worked under the code name "László Kaposvári" was a 45-year-old hospital physician in Sopron. In 1975, he shared the story of a young female neurology patient with his case officer. The composition of the report suggests formal and logical deliberateness. In the first part, relying on the information shared by the patient's father, "Kaposvári" recounts the underlying reasons for hospitalization and the circumstances of the onset of her daughter's illness: "According to the father, his daughter was hospitalized because she was recruited by two agents of the state security in Sopron. [...] They even gave her money so that she could cover her expenses when she meets suspicious

36 ÁBTL 3.1.2. M-31222 “Szentendrei," 43-45. Report, Pomáz, January 26, 1968.

37 On the origins of the medical gaze, its transformation, and role in medicine in more detail see Foucault, The Birth of the Clinic. 
persons [who wish to flee the county]." 38 The report then reflects on the need for hospitalization because of an "occupational disease." Though the following sections of the anamnesis were mostly anonymized, the available details suggest that the condition of the patient was analyzed further.

If we interpret the report with the state security's gaze in mind, the story of a de-conspired informant unfolds. However, if we consider that "Kaposvári" also used the specific methodology of medical knowledge production to construct the narrative, another possible interpretation is implied. Reliance on the father's account could imply that the report was constructed similarly to a heteroanamnesis. ${ }^{39}$ In this, the patient's condition is clearly interpreted as an "occupational disease." This explanation is then mirrored in the doctor's diagnosis. Therefore, the report highlighted the risks of the agents' work to the individual's health, even though the original aim of the report was to indicate possible threats to the state socialist system, for example, seditious behavior. ${ }^{40}$ This also meant that "Kaposvári" not only ignored the prescribed standards of report writing but also favored the individual's interests as opposed to the society's (or the regime's). Bearing this in mind, it is rather striking that the case officer accepted his report without criticizing its form and content.

"Kaposvári" was not the only person who applied the same methodology used in medical diagnostics to interpret information reported to the secret police. A man who went by the name "Hegyi" also used this method on some occasions between the 1960s and 1970s. "Hegyi" was the primary physician ${ }^{41}$ of the Intapuszta Institute of Work Therapy, located close to the Austrian border. Owing to his position and wide social network, ${ }^{42}$ he was considered a potentially "useful" informant, and his recruitment was of great importance to the state security forces. His dossier contains two reports, the subjects of which had valuable relationships with people abroad. He characterized them as follows:

38 ÁBTL 3.1.2. M-37256. “Kaposvári László.” Report, Győr, January 30, 1975. 24-25.

39 Heteroanamnesis means that it is not the patient who gives an account of his or her own medical history, complaints, or the circumstances of, for example, an accident, but others, such as family members or an eyewitness.

40 The social tendencies in state socialist systems and their possible links to psychiatric conditions have already been discussed in detail. In the case of Hungary, see for example Kovai, "Számtalan forró csókkal”; Csikós, "Countryside Modernized or Traumatized?” On the GDR, see: Bonhomme, "Le Mur lui."

41 The everyday life of this institution prior to "Hegyi's" directorship was depicted by István Benedek (Benedek, The Gilded Cage.) After "Hegyi" left the institution, "Szentendrei" was appointed as primary physician.

42 One of these acquaintances was the psychologist Ferenc Mérei, who was under surveillance and attacks by the authorities for both his professional and personal activities. 
In my estimation, the onset of his lunacy was around '54 or' 55 , with the appearance of paranoid delusions. [...] From a psychiatric point of view, his current condition could be evaluated as follows: he is in a balanced state, which means neither recovery nor health. Any unexpected event or trauma, in fact, any curious occurrence could induce remission. [...] I do not think he could give any valuable information, as he has been hospitalized for approximately $15-16$ years. ${ }^{43}$

He recounted that at work he had many conflicts because of his drinking, sometimes he showed up to work drunk. [...] As we say, he suffers from chronic alcoholism. [...] I would say that because of his obscure relations, he could be useful [...] though not for obtaining information, rather for some other assignments, as he is an existentially unstable, unreliable person. ${ }^{44}$

The reports from which these rather expressive passages are quoted can be divided into three lengthy sections. In the first part, "Hegyi" discusses the individual's past and his or her preceding medical conditions in detail. The wording and underlying logic of these narratives evoke the structure and content of anamneses: they detail the evolution of symptoms and the changes in the individuals' behavior in a chronological order. The anamnesis in these cases, however, not only functions as a standard medical method of questioning, but is also fundamental to the "social prognosis" presented to the case officer. "Hegyi," though he does not want to follow the logic of the state security forces in "reconstructing" his patients based what he was told, provides a thorough explanation for his medical observations in order to ensure that his case officer understands it properly. On the other hand, he characterizes the patients, who were potentially interesting for the secret police, in a narrative framework which was, owing to his professional, medical expertise, more "comfortable" for him than for the non-expert case officer. And although unusually an informant's work was evaluated by his or her case officer, in these particular cases, no evaluations were made, which might suggest that this recurring method was accepted by "Hegyi's" case officer.

It is rather difficult to determine, however, whether what these methods were part of a general tendency or were simply individual approaches to the composition of these specific narratives. Could medical knowledge play a part

43 ÁBTL 3.1.2. M-33556 "Hegyi.” Report, Szombathely, October 1, 1970, $258-61$.

44 ÁBTL 3.1.2. M-33556 "Hegyi." Report, Szombathely, November 12, 1970, 270-76. 
in procuring a more advantageous position in a situation when an informant was both an observer and someone under observation? Or did physicians who were also serving as informants simply use the routinized techniques of producing medical knowledge in another context? The doctors, logically, do not reflect on their choices of register in their reports, so a deeper analysis of the problem would require situations in which a possible change or break is detectable which then leads to the conscious use of medical knowledge tailored to new circumstances. I have only found one such case, that of "Orvos." 45

"Orvos" was a radiologist in Budapest and also an emblematic figure of the neo-avantgarde underground musical scene of the capital from the end of the 1950s. In 1960, he wrote a report on the potential spying activities of a clerical figure and employee of Orion, which was a state-owned company manufacturing telecommunications equipment. "Orvos" and the worker were introduced to each other by a friend on account of their common interest in speakers. In his report, "Orvos" described the worker as a well-prepared person in telecommunication. Born in Transylvania, he had a widespread network of friends and acquaintances abroad, and he traveled frequently to repair and sell radios. And even though his activities were suspicious in and of themselves, "Orvos" also added that his new acquaintance had several names, and his ID, which contained false information, was not valid. This report had significant relevance for the authorities, but the structure of the report was so chaotic that "Orvos," though he had already been working as an agent for nine years, was asked to revise it. Thereafter, "Orvos" made some changes to the report and amended it with a medical evaluation missing from the previous version: "Medical opinion. [...] I consider unverifiable and exclude personality change due to trauma or family and genetic inheritance. Though his interests are not monomaniac, his judgements are partly compulsive. Based on this, I consider his stories credible and true." "46 This addition suggests that after his earlier unsuccessful attempt, "Orvos" intended to use his medical knowledge to underline his opinion, assuming that medical knowledge is a socially accepted area of expertise of which he was in possession. His report suggests that the observed spy was, in fact, of sound mind and that his activities could indeed undermine the system. In this light, the value of "Orvos's" activity as an informant was significantly more valuable. The report was eventually accepted by the case officer and assessed as operationally valuable. Although "Orvos" was

45 "Orvos" (whose code name means doctor in Hungarian) is examined in a different role as one of the significant members of the underground musical scene of the Kádár era by Kürti, Glissando és húrtépés. 46 ÁBTL 3.1.2. M-17764/1 “Orvos.” Report, Budapest, December 3, 1960, 328-31. 
a radiologist and his medical description was based on psychiatric knowledge, his report could be considered acceptable and interpretable for two main reasons. First, as I mentioned at the beginning of my article, reflecting on mental problems and the nonconformist behavior of the target person or the informant was one of the recommended methods during state security observation. Second, the information given by "Orvos" may have been acceptable to the officer because, despite the officer's operational training, the officer presumably saw "Orvos" as having a more profound knowledge of psychology than he, the case officer, had.

Until now, I have focused on procedures and methods which are not strongly linked to the different fields of medicine but are generally true for physicians who work in an institutional context. The last three examples, however, show the significance of psychiatric and neurological expertise, since psychiatric and neurological expertise serve as the technology with which the patients are "reconstructed" in this new narrative context, outside of the medical field. This might be linked to the development of psychiatry as a discipline. Though psychiatry, especially with the broadening of neurological knowledge, was given a strongly biomedical character in the period, diagnosing "madness" required different "tests" that were meant to determine the normalcy or abnormality of the individual's behavior from the perspective of society at large. The social character of these tests does not mean, however, that they were not medically verifiable methods. They were created precisely to attest to the medical validity of the different technologies of mental normalization. ${ }^{47}$ From among the three doctors, only "Hegyi" had a confirmed background as a psychiatrist. Still, one does not necessarily have to be a specialist in psychiatry to give an account of the social and political implications of a patients' psychological functions, as physicians had all been required to appropriate the basics of psychiatry and neurology during their studies. Psychiatric knowledge, however, was one of the rare forms of medical expertise which was seen as enabling a physician to interpret patients' attitudes towards the norms of socialist society. This knowledge also made these reports valuable for the authorities, but at the same time, it did not expose the patients or the doctors to the discursive and hierarchic logic characteristic of the state security.

47 One of the techniques focusing on the individual's social existence is questioning, which might be oriented around previous moments in one's family and medical history to uncover the signs of madness. Foucault, Le pouvoir psychiatrique, 267-76. 
Differences in knowledge, social prestige, and hierarchy

As we have seen, the doctors examined so far did not use the expected discursive and logical patterns, but rather recreated the techniques of medical knowledge production in a new context. This seems to have been an accepted, even recurring method, as in most cases, the doctors were not ordered to revise and resubmit their reports, and sometimes the information obtained this way had considerable operational value. But what could explain the approval of these methods? It seems plausible that regardless of the applied discursive techniques, the reports were comprehensible for the case officers. In case of "Hegyi" and "Kaposvári," this interpretation could suffice. However, "Orvos's" case does not seem to fit into this logic: he first provided the information, which had considerable operational value, and then he amended his report with a medical explanation, and this explanation led to the acceptance of his report. Furthermore, the contentcentric explanation is weakened if we consider that expecting the informants to conform to the discursive logic prescribed by the state security also had a disciplinary aspect: the practice of ordering the informants to revise their reports was important in sustaining a hierarchical relationship. If the relationship between the case officer and the informant is understood more flexibly, taking other factors, for example, social prestige into consideration, we can find further explanations as to why medical knowledge was accepted by the officers as a methodology with which to interpret operationally valuable information.

One possible explanation is the high social prestige of doctors and medical knowledge. Doctors in state socialist societies, owing to their expertise in maintaining and restoring the health of workers, who were seen as the pillars of society, were of fundamental importance, and their positions were linked in both medical and sociological discourses to considerable social prestige. ${ }^{48}$ The first prestige analyses were carried out, however, only in the 1980s, in 1983 and 1988. The analyses underpinned the high social prestige of doctors: from among the 156 occupations under study, hospital physicians were ranked first and general practitioners fourth. ${ }^{49}$ As for the amount of expertise required to hold a certain

48 Though these publications are far from proper prestige analyses, they pinpoint the rapidly transforming social perception of doctors, which had wide social implications. See for example: Harmat, "Az orvosi tekintély," Lukáts, "Strukturális vizsgálódások," 73-75.

49 Though these analyses were done in the last decade of state socialism, its results could be relevant retrospectively. As the principal investigator pointed out, the social prestige of an occupation is a social value that is prone to change only slowly, and the 1983 and 1988, sociological investigations proved that the social and scientific value of doctors was gradually increasing. See Kulcsár, Foglalkozások presżtísse, 5-20, 27. 
position, hospital physicians were ranked first and general practitioners second, above all other occupations. Therefore, based on a representative sample, medical knowledge was considered the most valuable knowledge..$^{50}$

A second explanation is grounded on the quality and unapproachability of medical knowledge. Due to the gradual professionalization and specialization of the different fields of medicine and the proliferation of technologies, the production of medical knowledge became more specific and impenetrable for non-experts. ${ }^{51}$ Thus, the agent-doctors based their work within the network of state security on a form of knowledge and its methods of evaluation that were largely incomprehensible for outsiders. And even though public health policy strove to incorporate some elements of the "socialist self-consciousness" into the discourse and urged the members of society (the patients) to turn to medical ethics committees, ${ }^{52}$ the task and prerogative of evaluating the complaints and possibly issuing sanctions were still in the hands of medical experts, not laymen. If we accept this explanation, it is likely that even the possibility of criticizing medical knowledge was dismissed by laymen, who, in this case, were the officers of the state security forces.

\section{Opposition in the Wards}

The adaptability of medical knowledge and the doctors' positions, which rested on the solid foundation of the social value of their knowledge, presented something of a conundrum from the perspective of the state security forces. While their position in society was advantageous, as they could operate easily as observers in a wide social network, their expert knowledge made them unreliable, as they could manipulate the obtained information and mask potential seditious activities effortlessly. Consequently, the specific features of diagnostic and therapeutic practice and their social perceptions could enable doctors to elude the interpretive (and at the same time, disciplinary) methods dictated by the

50 The prestige of medical knowledge could be valorized because of the differences in the levels of (expert) knowledge between the doctor and his case officer. This aspect, however, can only be examined in the case of "Hegyi," as only his case officer's personal dossiers were kept in the archives. According to this, the officer, after having finished primary school, studied for two months in the party's school and the officer's training school in the 1950s. In 1965, he graduated from the Police College of the Ministry of Interior. These brief trainings offered ideological and technical knowledge, but they were not sufficient to convey extensive knowledge. (ÁBTL 2.8.1. BM Vas Megyei RKF, Personal Dossiers. 773.)

51 Horváth, "Orvosok - pedagógusok," 59-61.

52 On the principles of the committees and some sample cases see Szabó, Orvosetikai kérdéselkról. 
logic of the state security forces. What complicates this scheme is that applying the techniques of medical knowledge production in this new context implied the violation of professional norms and disregard for medical privacy. These explanations, however, are still insufficient to give a reassuring answer to my original research questions, because the above conclusions focus exclusively on the possibilities of obtaining information in a medical context. So far, I have not explored the phenomena strongly linked to medical activities that made the presence of doctors as the agents of state security services indispensable. Or to medicalize my inquiry: where did the blind spot of the secret police lie, a blind spot to which only doctors had access?

The secret police, as one of the fundamental networks of surveillance in the Kádár era, strove to uncover the secrets of individuals or certain groups and their attitudes towards social norms and to interpret the implications of their potentially threatening activities. Consequently, the secret police tried to infiltrate alternative spaces in society, for example, meetings among people belonging to intellectual circles or private art events that were for some reason hidden from the public eye. ${ }^{53}$ As for hospitals, the secret police was supposed to have easy access to any information, considering the public funding and extensive administrative practices of these institutions. Yet this was not always the case. Fortunately, some of the dossiers reveal exactly how permeable the walls of hospitals were and who had access to information produced within these spaces.

"Viola" worked as a physician at the First Department of Neurology of the hospital on Róbert Károly Boulevard. She was recruited because, in the hospital and especially at the neurology clinic, more people who had actively participated in the events of the 1956 Revolution were hidden. By the time "Viola" was recruited, the agents of the state security forces, who played a leading role in identifying and tracking "counterrevolutionaries" until 1963 (when a general amnesty was proclaimed), had already identified three such individuals. This could be seen as a success. However, by this time, already more than a year had passed since the revolution. Also, this particular institution played a particularly prominent role in serving the medical needs of the state socialist elite, especially the Hungarian army and the Soviet troops stationed in the country. These two facts may have cast a shadow on the efficiency of the agents' work in identifying the potential enemies of the system. Therefore, a doctor was needed to provide

53 This is exemplified by the dossiers of "Hegyi" and "Szentendrei," who had to provide information about Ferenc Mérei’s activities, for example the professional events he organized. 
an inner perspective and assist the police forces in their efforts to detect those hiding from retribution. That their reasoning in the assignment plan was sound was proven by "Viola" during their first meeting: she immediately named an individual who had successfully eluded the gaze of state security. The further analysis of the assignment plan also reveals that hospitals could serve as "asylums" for those who wanted to escape retribution. ${ }^{54}$ And as this example testifies, they sometimes hid in plain sight, but owing to the (partial) impermeability of the hospital's walls, doctors were indispensable in assisting the agents of the state security in exposing potential enemies.

The recruitment of "Viola" in 1958 could be explained either as a consequence of the relative closeness of the revolution in time or the efforts of the authorities to expose the enemies of the system. However, even when these circumstances did not hold, hospitals remained places of interest for the agents of the secret police, as the cases of "Kaposvári" and "Marossi Pál," a physician at the Second Department of Internal Medicine of the Medical University of Pécs, show.

"Marossi" was first asked to report on a patient in 1960. The patient, K. L., who had been at the clinic for months, was a religious person and had numerous visitors. Though "he was not visited by the priests of the Church of the Order of Mercy, he often called priests for fellow patients and strove to persuade others to follow his example. The directors of the clinic, however, prohibited him from continuing with such activities." ${ }^{55} \mathrm{~K}$. L.'s religiosity is emphasized throughout the report, and this explains why he was under surveillance. However, "Marossi" tried to divert the attention of the case officer from K. L.'s religiosity by making it seem as if it remained merely a private matter and did not influence the other patients.

54 Among health care institutions, psychiatric wards were particularly well suited to this asylum function. Comparing the methods of making a psychiatric diagnosis with the methods used in other medical disciplines, psychiatric diagnoses could be perceived as more subjective and blurred because they were first and foremost based on observations of individual behavior and decisions that were made according to social norms instead of physiological symptoms. Thus, it could be easier to fake a psychiatric diagnosis than any other medical diagnosis. This social aspect of psychiatry was exploited in cases concerning politically threatening individuals in Hungary and also in the Soviet Union, if we consider the well-known practice of political psychiatry. In the case of Soviet political psychiatry and its most common diagnosis (sluggish schizophrenia, a disease that could be hardly verified by solid evidence), the state confined individuals to concealed wards. As the sources under study testify, the Hungarian case was the other way around. The individuals and their doctors took advantage of this aspect of psychiatry.

55 ÁBTL 3.1.2. M-17361. “Marossi Pál” Report, Pécs, August 16, 1960, 326. 
Like "Marossi," "Kaposvári" also gave an account of his patients' behavior in the wards. He reported that "Mrs. H. A., a teacher from Sopron, listens to Radio Free Europe daily, though she does not share what she has heard with the others." Upon evaluation, "Kaposvári”" added the following: "Mrs. H. A. listens to Radio Free Europe again. However, her roommate is hard of hearing, and thus she does not know which frequency her roommate listens to."56 According to a 1953 court decision, listening to RFE was not prohibited as long as it was not done in public. "Kaposvári," who presumably was familiar with the court decision, by referring to the hearing loss of Mrs. H. A.'s roommate, tailored his report to the norms and expectations of socialism, and he used a medical explanation to minimize the possibility of any drastic measures being taken by the police. Although the informants never knew what the State Security Service would do with the information obtained through them and or what consequences their contributions to the system would have for the individuals "denounced," according to the report issued by "Kaposvári," the patient had not violated any rules, so the report qualified as operationally valuable, and the agents of the state security remained alert.

The cases of "Kaposvári" and "Marossi" reveal that the individuals under surveillance were already known by the secret police, and their stay in the hospital was seen as a period that could be instrumental in uncovering their potential seditious activities. It was therefore particularly important, from the perspective of the authorities, to keep them under observation on account of their potentially threatening activities and the ideological influence they could exert on other patients. As both cases illustrate, the social space of hospitals was seen as a milieu in which listening to the RFE or engaging in religious activities that were tolerated if done in private could become subversive because of the impact they could have on other individuals. This is something that authorities could not turn a blind eye to. Furthermore, reports on the visitors who came to see these patients could shed light on the patients' social networks, which in turn could assist the authorities in tracking other potentially dangerous individuals.

Observing the behavior of patients was only one possible reason for the active presence of the secret police in medical institutions. As the cases of "Lénárd Pál" and "Angyalföldi" illustrate, other, more complex problems of socialist healthcare could come to the surface, which, in addition, could shed

56 ÁBTL 3.1.2. M-37256. "Kaposvári László” Report, Győr, January 30, 1975, 23 -24. 
light on the common violation of norms by either doctors or their patients. ${ }^{57}$ While "Angyalföldi" reported on the practice of prioritizing Yugoslavian patients, who paid in foreign currency for medical services, to the detriment of insured Hungarian patients, "Lénárd Pál," a neurologist at the Székesfehérvár hospital, wanted to declare a patient who had already suffered of ill health an invalid. However, in doing so, encouraged by his case officer, "Lénárd" did not follow the usual, official route, but rather bribed other physicians, a seemingly common method for declaring healthy individuals invalids. Though the two situations differ, the aim in both cases was to uncover activities that had already been known broadly, but the authorities were in need of more information (names, venues, dates) to move forward. These were significant details that nonmedical personae would not have been able to unearth. The above situations also demonstrate that hospitals, even though they were intended, in principle, to serve the wellbeing of society, could function as institutions in which the evasion of norms was rather frequent.

The last five cases prove that hospitals and wards enabled subversion and could serve as hiding places for enemies of the state and at the same time could effectively conceal these activities. The impermeability of the hospital's walls is due to its function as a total institution. As Erving Goffman points out, hospitals and similar institutions, such as prisons, monasteries, and schools, have a special, socializing function either to habituate individuals to follow norms or to correct their behavior. If these institutions are going to perform this function successfully, any passage between the inner world of the institutions and the "real" world outside must be severely restricted. The physical and mental separation of the two spaces could mean reformulating the rules and norms of the outside world, all the while creating a new order within the walls of the institutions. ${ }^{58}$ The agent-doctors, therefore, could offer a glimpse into a segment of social space that would have been impenetrable without their cooperation. At the same time, this impermeability meant that they had some autonomy in selecting the information to be shared or concealed..$^{59}$

57 These were recurring topics in both of their reports. See for example: ÁBTL 3.1.2. M-39640 "Lénárd Pál” Report, Székesfehérvár, December 29, 1979, 12-20; ÁBTL 3.1.2. M-39489 “Angyalföldi” Report, Békéscsaba, October 17, 1979, 23-29.

58 Goffman, Asylums, 1-125.

59 In the course of my research, I have not come across any instances in which case officers doublechecked the operationally valuable details provided by doctors, even though this kind of double-checking was a commonly used method of confirming information. Moreover, based on these results, it would be interesting to examine how the aforementioned "impermeability" of hospital walls and the autonomy of 


\section{Conclusion}

In this study, I have offered several concrete cases illustrating ways in which doctors maneuvered within the network of the state security forces, one of the most significant institutions of state socialist societies responsible for the surveillance and control of individuals. A physician's adherence to professional norms, expertise, and institutional position made him or her a potentially valuable asset in the eyes of the authorities. It was not as simple to exploit this potential, however, as it may have seemed initially. Though on many occasions, the doctors' performance as agents was assessed positively by their case officers, the doctors often failed to follow the prescribed norms of construing the enemy. The gray zone between the standard practices of the state security forces and medical activities denotes social spaces which the authorities would have been unable to permeate without the assistance of medical practitioners. At the same time, this points at a specific quality of medical knowledge that made these spaces inaccessible for outsiders, thus facilitating social resistance, at least to some extent.

I have also attempted to underline that, following Foucault's argument, the affiliation between doctors and their case officers exerted an influence through relationships and institutions. In the framework of the strongly hierarchical operations of the state security forces, the social position of physicians also came into prominence, and in this context, this social position gave physicians a certain amount of autonomy. In the future, this aspect should be explored in further detail, using a wider array of sources which could shed light on the extent to which the publicly funded healthcare system and its publicly financed employees could realize their autonomy from the state in other respects, such as medical education and primary care.

physicians was extended and also to consider the roles played by the location of institutions (rural, urban, or metropolitan institutions) and their specialization in this relative independence. 


\section{Appendix}

Table 1.

\begin{tabular}{|l|l|l|c|l|}
\hline Name & Specialty & Place of operation & Year of birth & Role in the network \\
\hline "Viola" & Psychiatrist & Budapest & 1925 & Agent \\
\hline "Tarkői" & GP/surgeon & Eger & 1925 & Informant \\
\hline "Marossi Pál" & Internist & Pécs & 1921 & Agent \\
\hline Orvos" & Radiologist & Budapest & 1931 & Agent \\
\hline "Siva" & GP/ophthalmologist & Kalocsa & 1924 & $\begin{array}{l}\text { Agent (until 1958) } \\
\text { Thereafter: informant }\end{array}$ \\
\hline "Szzentendrei" & Psychiatrist & Pomáz & 1931 & Informant \\
\hline "Hegyi" & Psychiatrist & Intapuszta & 1922 & Informant \\
\hline $\begin{array}{l}\text { "Kaposvári } \\
\text { László" }\end{array}$ & Pulmonologist & Sopron & 1930 & Secret emissary \\
\hline "Angyalföldi" & Internist & Békéscsaba & 1950 & Secret emissary \\
\hline "Lénárd Pál" & Neurologist & Székesfehérvár & 1945 & Secret emissary \\
\hline
\end{tabular}

\section{Archival Sources}

Állambiztonsági Szolgálatok Történeti Levéltára [Historical Archives of the Hungarian State Security] (ÁBTL)

2.8.1. BM Vas Megyei RFK személyi gyüjtők [Ministry of the Interior, Vas County Police Headquarters, Personal dossiers]

3.1.1. B-84186 "Viola"

3.1.1. B-92993 "Tarkői”"

3.1.2 M-17361 "Marossi Pál”

3.1.2. M-17764/1 “Orvos”

3.1.2. M-18864/1 "Siva”

3.1.2. M-31222 "Szentendrei”

3.1.2. M-33556 "Hegyi”

3.1.2. M-37256 "Kaposvári László"

3.1.2. M-39489 "Angyalföldi"

\subsubsection{M-39640 "Lénárd Pál"}

4.1 A-3120. Ivanin, G. I. Az operatív pszichológia néhány kérdése [Some questions of operative psychology]. Moscow, 1973.

4.1. A-3121. Láng György. Operatív pszichológia III. A hírszerzés hálózata vezetésének és nevelésének szociálpszichológiai kérdései [Operative psychology 
III. Some questions of social psychology on leading and training the members of intelligence services].

4.1 A-4510. Horváth István. A pszichológia és szociálpszichológia felhasználása hálózati munkában [Using psychology and social psychology in the work of intelligence services]. Thesis.

Decree No. 8. Medical Regulation, 1959.

11/1972. (30. VI.), Regulation of medical workers, issued by the Ministry of Health.

\section{Bibliography}

Balint, Michael. "The Doctor, the Patient and the Illness." The Lancet, 265, no. 6866 (1955): 683-88.

Bates, Vicoria. "Yesterday's Doctors: The Human Aspects of Medical Education in Britain, 1957-93." Medical History 61, no. 1 (2017): 48-65. doi: 10.1017/ mdh.2016.100.

Benedek, István. The Gilded Cage. Budapest: Corvina Press, 1965.

Bernstein, Frances L. "Behind the Closed Door: VD and Medical Secrecy in Early Soviet Medicine." In Soviet Medicine: Culture, Practice and Science, edited by Bernstein, Francis L., Burton, Christopher, Healey Dan, 92-110. Dekalb: Northern Illinois University Press, 2010.

Betts, Paul. Within Walls: Private Life in the German Democratic Republic. Oxford: Oxford University Press, 2010.

Blum, Alan. The Grey Zone of Health and Illness. Bristol-Chicago: Intellect, 2011.

Bolgár, Dániel. "A hatalom mindennapjai: Azonosítási játék az államvédelemnél" [The everyday life of power: A game of identification at the state security]. 2000 23, no. 11 (2011): 3-13.

Borhi, László. Hungary in the Cold War, 1945-1956: Between the United States and the Soviet Union. Budapest: Central European University Press, 2004.

Csikós, Gábor. "Countryside Modernized or Traumatized? Rural Mental Health in Hungary after the Collectivization of Agriculture.” Hiperboreea 7, no. 1 (2020): 74 98. doi: 10.5325/hiperboreea.7.1.0074.

Deleuze, Gilles. Foucault. Paris: Les Editions de Minuit, 2004.

Farádi, László. “Dialektikus materializmus a gyakorló orvosi tevékenységben” [Dialectic materialism in medical practice]. Katonaorvosi Sžmle 5, no. 9 (1953): 817-22.

Foucault, Michel. Discipline and Punish. The Birth of Prison. New York: Vintage Books, 1977. 
Foucault, Michel. "The eye of power." In Power/Knowledge: Selected Interviews and Other Writings, 1972-1977, edited by C. Gordon, 146-65. New York: Vintage Books, 1980.

Foucault, Michel. The Birth of the Clinic: An Archaeology of Medical Perception. New York: Vintage Books, 1994

Foucault, Michel. Le pouvoir psychiatrique: Cours an Collège de France, 1973-1974. Paris: Gallimard Seuil, 2001.

Fulbrook, Mary. “The Concept of 'Normalization' and the GDR in Comparative Perspective." In Power and Society in the GDR, 1961-1979: The "Normalisation of Rules"?, edited by Mary Fulbrook, 1-30. New York: Berghan Books, 2009.

Fülöp, Tamás. Néhány tökés ország egészségügyének szervezete: Az egészségügy nemz̨etközi szuervei [The healthcare system of some capitalist countries: The international organizations of healthcare.] Budapest, 1962.

Goffman, Erving. Asylums: Essays on the Social Situation of Mental Patients and Other Inmates. New York: Anchor Books, 1961.

Gyarmati, György, and Tibor Valuch. Hungary under Soviet Domination. New York: Columbia University Press, 2009.

Hancock, Black Hawk. "Michel Foucault and the Problematics of Power: Theorizing DTCA and Medicalized Subjectivity." The Journal of Medicine and Philosophy: A Forum for Bioethics and Philosophy of Medicine 43, no. 4 (2018): 439-68. doi: 10.1093/jmp/jhy010.

Harmat, Pál. "Az orvosi tekintély változása korunkban" [The transformation of the medical profession's prestige in our age]. Orvosi Hetilap 119, no. 11 (1978): 32-35.

Horváth, Sándor. "Life of an Agent: Re-Energizing Stalinism and Learning the Language of Collaboration after 1956 in Hungary." Hungarian Historical Review 4, no. 1 (2015): 56-81.

Horváth, Sándor. "A helytörténetírás mint 'szürke zóna' és kulturális ellenállás a szocialista korszakban" [Local history as a "gray zone" and cultural opposition in the socialist era]. In Az ember helye - a hely embere: A helytörténetírás módszertani kérdései [The place of man - the man of the place: The methodological questions of writing local history], edited by István Lengvári, Mónika Pilkhoffer, József Vonyó, 88-99. Budapest-Pécs: Magyar Történelmi Társulat-Kronosz-MTA Pécsi területi Bizottsága, 2019.

Horváth, Attila. "Orvosok - pedagógusok" [Doctors - teachers]. Valóság 29, no.4 (1986): 59-67.

Hosking, Geoffrey. "Trust and Distrust in the USSR: An Overview." The Slavonic and East European Review 91, no. 1 (2013): 1-25. doi: 10.5699/slaveasteurorev2.91.1.0001. 
Koltai, Gábor. Akik a "Párt" ellen vétkęztek [Those who wronged the "Party"]. Budapest: Korall, 2019.

Kovai, Melinda. “'Számlálatlan forró csókkal' - Állambiztonsági megfigyelés a Kádárkorszak pszichiátriai kórrajzain" ["With countless fervent kisses" - State security observation on the psychiatric case histories of the Kádár era]. Forrás 43, 7-8 (2011): 159-76.

Kulcsár, Rózsa. Foglalkozások preszțíse [The prestige of occupations]. Budapest: KSH, 1990.

Kürti, Emese. Glissando és húrtépés: Kortárs zene és neoavantgard müvészet az, underground magánterekben, 1958-1970 [Glissando and string tearing: Contemporary music and neo-avantgarde art in underground private spaces, 1958-1970]. Budapest: L'Harmattan, 2018.

Le Bonhomme, Fanny. "'Le Mur lui est monté à la tête’: Construction du mur de Berlin et basculement dans la maladie (Berlin-Est, 1961-1968)." Le mouvement social 253, no. 4 (2015): 31-47. doi: 10.3917/lms.253.0031.

Light, Donald W. "Universal Health Care: Lessons from the British Experience." American Journal of Public Health93, no. 1 (2003): 25-30. doi: 10.2105/ajph.93.1.25.

Losonczi, Ágens. A kiszolgáltatottság anatómiája az egészségügyben [The anatomy of vulnerability in healthcare]. Budapest: Magvető, 1986.

Lukáts Jenő. "Strukturális vizsgálódások a magyar orvostársadalomban: Az orvosi réteg helye, szerepe a társadalomban" [Structural examinations in the Hungarian medical society: The place and role of medical professionals in society]. Politika-tudomány 1 , no. 1-2 (1971): 73-110.

Peerson, Anita. "Foucault and the Modern Medicine." Nursing Inquiry 2, no. 2 (1995): 106-14. doi: 10.1111/j.1440-1800.1995.tb00073.x.

Rainer M., János. Jelentések bálójában: Antall József és az állambiẓtonság emberei 1957-1989

[In the web of reports: József Antall and the personnel of state security, 19571989]. Budapest: 1956-os Intézet, 2008.

Szabó Ferenc. Orvosetikai kérdésekról [On some questions of medical ethics]. Budapest: Medicina, 1973.

Szalai, Júlia. Az egészségügy betegségei [The maladies of healthcare]. Budapest: Közgazdasági és Jogi Könyvkiadó, 1986.

Takács, Tibor. "Az ügynökhálózat társadalomtörténeti kutatása" [Social historical research of the agent network].

In Az ügynök arcai: Minennapi kollaboráció és aq ügynökkérdés [The faces of the agent: Everyday collaboration and the question of secret police agents], edited by Sándor Horváth, 107-30. Budapest: Libri, 2014. 
Van Dijk, Wieteke, Marjan J. Meinders, Tanke, Marit A.C., Westert, Gert P., Jeurissen, Patrick P.T. "Medicalization Defined in Empirical Contexts - A Scoping Review." International Journal of Health Policy Management 9, no. 8 (2020): 34. doi: 10.15171/ IJHPM.2019.101.

Vatulescu, Cristina. Police Aesthetics: Literature, Film and the Secret Police in Soviet Time. Stanford: Stanford University Press, 2010.

Verdery, Katherine. Secrets and Truths: Ethnography in the Archive of Romania's Secret Police. Budapest: CEU Press, 2014.

Weil, Francesca. Zielgruppe Ärzteschaft: Ärzte als inoffizielle Mitarbeiter des Ministeriums für Staatssicherheit. Berichte und Studien 54. Hannah Arendt Institut für Totalitarismusforschung 5. Göttingen: Vandenhoeck \& Ruprecht Unipress, 2008. 